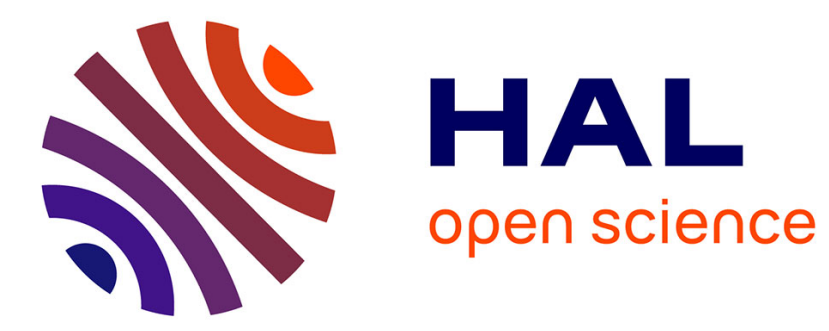

\title{
HIV-positive in the darkness of a correctional facility: more vulnerable and less treated
}

\author{
Florence Huber, Stéphanie Vandentorren, Alice Merceron, Amandine
}

Chaponnay, Gueda Gadio, Vincent About, Agathe Pastre, Mathieu Nacher

\section{- To cite this version:}

Florence Huber, Stéphanie Vandentorren, Alice Merceron, Amandine Chaponnay, Gueda Gadio, et al.. HIV-positive in the darkness of a correctional facility: more vulnerable and less treated. International Journal of STD and AIDS, 2019, 30 (5), pp.460-466. 10.1177/0956462418816452 . hal-02497672

\section{HAL Id: hal-02497672 \\ https://hal.science/hal-02497672}

Submitted on 3 Mar 2020

HAL is a multi-disciplinary open access archive for the deposit and dissemination of scientific research documents, whether they are published or not. The documents may come from teaching and research institutions in France or abroad, or from public or private research centers.
L'archive ouverte pluridisciplinaire HAL, est destinée au dépôt et à la diffusion de documents scientifiques de niveau recherche, publiés ou non, émanant des établissements d'enseignement et de recherche français ou étrangers, des laboratoires publics ou privés. 


\title{
Page Proof Instructions and Queries
}

\author{
Journal Title: International Journal of STD \& AIDS (STD) \\ Article Number: 816452
}

Thank you for choosing to publish with us. This is your final opportunity to ensure your article will be accurate at publication. Please review your proof carefully and respond to the queries using the circled tools in the image below, which are available by clicking "Comment" from the right-side menu in Adobe Reader DC.*

Please use only the tools circled in the image, as edits via other tools/methods can be lost during file conversion. For comments, questions, or formatting requests, please use $\mathrm{T}$. Please do not use comment bubbles/sticky notes $\supseteqq$.

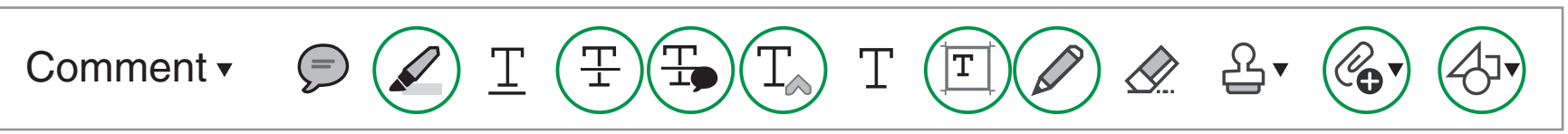

*If you do not see these tools, please ensure you have opened this file with Adobe Reader DC, available for free at get.adobe.com/reader or by going to Help > Check for Updates within other versions of Reader. For more detailed instructions, please see us.sagepub.com/ReaderXProofs.

\begin{tabular}{|c|c|}
\hline No. & Query \\
\hline & $\begin{array}{l}\text { Please note, only ORCID iDs validated prior to arcentance will be authorized for publication; we are unable to } \\
\text { add or amend ORCID iDs at this stage. }\end{array}$ \\
\hline & Please confirm that all author information, including names, affiliations, sequence, and contact details, is correc \\
\hline & $\begin{array}{l}\text { Please review the entire document for typographical errors, mathematical errors, and any other necessary } \\
\text { corrections; check headings, tables, and figures. }\end{array}$ \\
\hline & Please confirm that the Funding and Conflict of Interest statements are accurate. ${ }_{\AA}$ \\
\hline & $\begin{array}{l}\text { Please ensure that you have obtained and enclosed all necessary permissions for the reproduction of artistic works, } \\
\text { (e.g. illustrations, photographs, charts, maps, other visual material, etc.) not owned by yourself. Please refer to } \\
\text { your publishing agreement for further information. }\end{array}$ \\
\hline & $\begin{array}{l}\text { Please note that this proof represents your final opportunity to review your article prior to publication, so please } \\
\text { do send all of your changes now. }\end{array}$ \\
\hline AQ: 1 & Please provide Department or Faculty details in affiliation $1_{1}$ \\
\hline AQ: 2 & "PLWHIV" has been changed to "PLHIV" as per journal style. Please check. \\
\hline AQ: 3 & Is it "statistical analyses" or "statistical analysis"? Please check. \\
\hline AQ: 4 & Please update references $3,13,14,21$ \\
\hline AQ: 5 & Please provide page range in references $7,42$. \\
\hline AQ: 6 & Please provide publisher and location details in reference 12. \\
\hline AQ: 7 & Please provide website and accessed date in references 16,31 \\
\hline AQ: 8 & Please check whether details are set correctly in reference 28 \\
\hline AQ: 9 & Please provide volume number in reference 29 \\
\hline AQ: 10 & Please provide volume number in reference $30_{2}$ \\
\hline AQ: 11 & Please define abbreviations DAI-HIV and HTLV1 in Table 1. \\
\hline
\end{tabular}




\section{HIV-positive in the darkness of a correctional facility: more vulnerable and less treated}

International Journal of STD \& AIDS 0(0) 1-7

(C) The Author(s) 2018 Article reuse guidelines: sagepub.com/journals-permissions DOI: $10.1 \mid 77 / 0956462418816452$ journals.sagepub.com/home/std (S)AGE

\author{
Florence Huber ${ }^{1,2,3} \mathbb{D}$, Stephanie Vandentorren ${ }^{4,5}$, \\ Alice Merceron', Amandine Chaponnay ${ }^{2}$, Gueda Gadio',3, \\ Vincent About ${ }^{6}$, Agathe Pastre ${ }^{6}$ and Mathieu Nacher ${ }^{1,2,3,7}$
}

\begin{abstract}
In French Guiana, 4.5-5.0\% of HIV-infected persons experienced an incarceration between 2007 and 20I3. A crosssectional survey was performed to describe the epidemiology and treatment outcomes of a population of HIV-infected inmates in French Guiana. The study population was patients released between I/2007 and I2/20I3, after >30 days of incarceration $(n=147)$. A secondary objective aimed to identify its main specificities, relative to both the general inmate population and the nonincarcerated HIV population. The socioeconomic situation of HIV-infected inmates was particularly precarious, relative to other detainees: $58.1 \%$ had never attended school (versus $5.5 \%, p<0.01$ ), $31.0 \%$ were homeless (versus $8.5 \%, \mathrm{p}<0.0 \mathrm{I}$ ), $63.9 \%$ were repeat offenders (versus $46.6 \%, \mathrm{p}<0.0 \mathrm{l}$ ), $33.3 \%$ were crack cocaine users (versus $9.8-12 \%, \mathrm{P}<0.0 \mathrm{I}$ ). The frequency of hypertension and chronic $\mathrm{B}$ hepatitis was also higher. Only $50.3 \%$ of inmates were on antiretroviral therapy (ART) versus $92.6 \%$ in the hospital HIV population $(\mathrm{p}<0.00 \mathrm{I})$. Among untreated patients, $15.1 \%$ refused ART. Among those treated, $81.3 \%$ were virologically suppressed. Although comparisons were biased, HIV-positive inmates had more psychosocial vulnerabilities than the general inmate population. Despite ART availability and excellent treatment outcomes, undertreatment was a fact not completely explained by patient refusal. HIV-infected inmates should benefit from increased attention by health care and social workers.
\end{abstract}

\title{
Keywords
}

AIDS, prison, antiretroviral therapy, psychosocial deprivation, substance-related disorders

Date received: 4 July 2018; accepted: 3 November 2018

\section{Introduction}

The inmate population concentrates vulnerable populations, regarding socioeconomic and life trajectory indicators. Thus, most inmates are young men, with an overrepresentation of low educational levels, lowskilled occupations, and foreigners. ${ }^{1,2}$ This social vulnerability is linked with a high prevalence of infectious diseases and mental health disorders. ${ }^{3-5}$ In some regions, HIV prevalence may be 6-50 times higher in correctional facilities than in the general adult population. ${ }^{6}$ Among inmates, HIV prevalence of up to $10 \%$ have been reported in 20 countries in Central Asia, Africa, Eastern Europe (Estonia, Romania, Slovakia, Lithuania, Ukraine), South America (12.5-17\% in Brazil), or in the Caribbean $\left(8-25 \%\right.$ in Cuba). ${ }^{6}$ In France, the PREVACAR survey (2010) estimated

\footnotetext{
'Université de Guyane, Cayenne, France [AQ1]

${ }^{2}$ COREVIH Guyane, Centre Hospitalier André Rosemon,

Cayenne, France

${ }^{3}$ Réseau Kikiwi, Cayenne, France

${ }^{4}$ Department of Social Epidemiology, INSERM, Sorbonne Université, Institut Pierre Louis d'Epidémiologie et de Santé Publique (IPLESP), Paris, France

${ }^{5}$ Santé Publique France, French National Public Health Agency, lle-deFrance Intervention Unit, Saint-Maurice, France

${ }^{6}$ UCSA, Centre Hospitalier André Rosemon, Cayenne, France

${ }^{7}$ Inserm CIC Antilles-Guyane INSERM I 424 (Pole Guyane), Université de Guyane, Cayenne, France
}

\section{Corresponding author:}

Florence Huber, COREVIH Guyane, Centre Hospitalier André Rosemon, Av. des Flamboyants, Cayenne 97306, France.

Email: florence.huber@ch-cayenne.fr 
that $2.0 \%$ of inmates were infected with HIV (CI: 0.9-4.2), which was about six times the national prevalence. $^{7}$

Although HIV-infected inmates have been described as a vulnerable population, ${ }^{8}$ only a few studies specifically focused on the vulnerability profile of HIV-positive inmates. ${ }^{9-11}$

French Guiana, a territory of 250,000 inhabitants located in South America, is the French territory with the highest HIV prevalence. With approximately $4 \%$ of HIV infection among detainees, it can be estimated that the prevalence is 3-4 times that of the general adult population in the region. ${ }^{12}$ The French Guiana penitentiary center includes a prison for men (sentenced for longer than two years), a jail for men (awaiting trial or sentenced for a duration shorter than two years), and another jail for women. Medical care is provided on site, at the outpatient care department, by general practitioners. Between 2007 and 2013, an infectious disease specialist was offering consultations for HIV care three half-days a month. [AQ2]After release, people living with HIV (PLHIV) are referred to one of the public sector specialized outpatient unit or more rarely to a general practitioner. The professionals in charge of HIV follow-up have access to an electronic medical record (NADIS), which is shared across French Guiana.

We have recently shown the great vulnerability of detainees in French Guiana in terms of mental health ${ }^{13,14}$ and the high mortality of HIV-infected inmates after release from incarceration. ${ }^{15}$

In this context, the aim of this study was to describe the population of PLHIV incarcerated in French Guiana, notably its psychosocial vulnerability factors, access to antiretroviral therapy (ART), and treatment outcomes. A secondary objective aimed to identify its main specificities, relative to both the general inmate population of the same correctional facility and the nonincarcerated HIV-infected population of the closest hospital.

\section{Methods}

\section{Study population}

We conducted a cross-sectional study. The study population was the participants of the DAI-HIV retrospective cohort. ${ }^{16}$ The primary objective of the DAI-HIV study was to determine the prognosis and the medical follow-up of PLHIV released from the French Guiana correctional facility between 2007 and 2013. All adult patients ( $\geq 18$ years) released from the French Guiana correctional facility between 1 January 2007 and 31 December 2013, after incarcerations of more than 30 days, were included in the DAI-HIV study $(n=147)$.
The main source of data was the electronic medical record NADIS, used for HIV follow-up at the regional level. Patients were asked to sign a consent form before their data were included in NADIS. Additional data were collected from paper medical files used for routine medical care in the correctional facility and the registries of the three hospitals of French Guiana. Data were recorded manually, by a medical doctor, with respect of confidentiality. The study protocol was approved by the Ethics Committee of Cayenne Hospital and declared to the Commission Nationale de l'Informatique et des Libertés, under the number $1975083 \mathrm{v} 0$.

The variables of interest were factors associated with vulnerability of PLHIV in previous publications: ${ }^{8,17-24}$ sociodemographic data (gender, age, migration, educational level), recidivism, homelessness, addictions, notably crack cocaine, a suspected driver of the HIV infection that is very frequent in French Guiana and leads to psychosocial isolation. ${ }^{25-27}$ Other health problems were also reported. Regarding HIV infection, the CDC stage, previous ART prescriptions, and immunovirological results (CD4 cell count, HIV viral load, which are usually used for the evaluation of HIV treatment ${ }^{28}$ ) were collected. HIV sexual risks and health insurance coverage on admission, which are often reported in studies on HIV among inmates, were not recorded in the DAI-VIH study.

\section{Other data mobilized}

To contrast the result of this specific population, comparisons were made with the general inmate population, and with the population of HIV-infected patients followed in the closest outpatient unit, in Cayenne hospital. The sources of data mobilized for comparative analyses were as follows:

- For the population of PLHIV followed in hospital: the VESPA2 population (2011), restricted to patients of French Guiana. ${ }^{29,30}$

- For the population of inmates: the correctional facility medical unit activity report ${ }^{12}$ and the KAP survey performed among detainees, in $2015 .^{31}$

The VESPA2 study is a cross-sectional survey, designed to describe the characteristics of PLHIV followed in the French territories. Eligible patients were at least 18 years old and HIV1 infected. For the French Guiana substudy, they were followed in the territory for at least six months. Only patients from the main hospital (Cayenne Hospital) were included in the French Guiana VESPA2 subsurvey, which accounted for about $60-65 \%$ of the PLHIV followed in the territory. After randomization, patients were interviewed face to face, using standardized questionnaires. ${ }^{29}$ 
The KAP survey 'Knowledge, attitudes and practices towards HIV and STDs among the prisoners, in French Guiana' is a cross-sectional survey, performed in the French Guiana Correctional facility. It documented the socioeconomic profile of inmates and identified the level of knowledge and risks of HIV transmission. After randomization, 236 detainees were interviewed $(78.7 \%$ of the randomized sample), by standardized questionnaires administered face to face, available in five languages. ${ }^{31}$

We performed descriptive analysis, with Stata Software. Pearson's Chi square test was used for statistical analyses, to compare the proportions between the different subpopulation, after verifying that the test conditions were met. [AQ3]

\section{Results}

\section{The DAI-VIH population}

Most inmates of the DAI-HIV study were newly diagnosed with HIV while incarcerated $(56.5 \%)$. The difference was significant between inmates born in France $(43.5 \%)$ and migrants $(62.4 \%), p=0.03$.

At the time of index incarceration (the last of the inclusion period), most patients had an early stage HIV infection: $78.1 \%$ CDC-A, $4.8 \%$ B-stage, and $17.1 \%$ C-stage. On admission, the median CD4 cell count result was $397 \mathrm{CD} 4 / \mathrm{mm}^{3}$, and $78.2 \%$ had a CD4 nadir $<500 / \mathrm{mm}$ among the documented observations $(\mathrm{n}=133)$.

On discharge $50.3 \%$ of the patients were on ART, compared to $29.9 \%$ on admission $(\mathrm{p}<0.01)$. Among those not on ART, 15.1\% $(n=11)$ had refused to take treatment, accounting for $7.5 \%$ of the total study population.

\section{Comparison of populations}

As shown in Table 1, the characteristics of the DAIVIH population seemed to differ from the PLHIV met in Cayenne hospital (VESPA2) and from the global population of detainees (KAP survey and UCSA activity report).

Indeed, the frequency of psychosocial vulnerability indicators was high among HIV-infected inmates, compared to the global population of detainees: a higher proportion were migrants $(69.4 \%$ versus $58.9 \%$, $\mathrm{p}=0.04)$, never attended school $(58.1 \%$ versus $5.5 \%$, $\mathrm{p}<0.01)$, were homeless or living in squats $(31.0 \%$ versus $8.5 \%, \quad p<0.01)$, were repeat offenders $(63.9 \%$ versus $46.6 \%, \mathrm{p}<0.01)$, were addicted to crack $(33.3 \%$ versus $9.8-12.0 \%, \mathrm{p}<0.01)$.

Besides that, $25.8 \%$ of the DAI-VIH population had a history of psychiatric disease, and $8.8 \%$ were diagnosed as psychotic. None were intravenous drug users, an unusual behavior in French Guiana.

Except for asthma, the prevalence of comorbidities seemed to be higher among HIV-positive inmates than in the general inmate population. Nevertheless, compared with the HIV-positive population followed in hospital care, the prevalence of $\mathrm{B}$ and $\mathrm{C}$ hepatitis, diabetes mellitus, and hypertension seemed to be similar.

\section{Discussion}

Between 4.5 and $5.0 \%$ of the PLHIV living in French Guiana experienced one or more incarceration during the period 2007-2013 (according to regional surveillance agency, approximately 3500 HIV-positive people lived in French Guiana at the end of 2014). In the USA, about $20 \%$ of PLHIV had been incarcerated in 1997 and $14 \%$ in $2009 .{ }^{32}$

Indeed, the doctrine 'zero tolerance' has spread in Europe from the United States since the 1990s. The expansion of this punitive trend has led to an increase in the detainee population, affecting mainly the poorest and marginalized populations. In France, the inmate population increased by 39\% between 1983 and $1997 .{ }^{33}$ Risk factors for incarceration ${ }^{1}$ are overrepresented among PLHIV: drug addiction, homelessness, ${ }^{34}$ unemployment, ${ }^{35}$ and poverty. ${ }^{36}$

Although the comparison of different proportions from different datasets must be taken with caution, they are useful to look for major patterns in the data. Our results (Table 1) suggest that HIV-positive inmates incarcerated in French Guiana have the same frequency of comorbidities than those observed among the PLHIV followed in the main hospital, with more frequent psychosocial vulnerability factors than those observed among the general inmate population: lack of education, history of migration, multiple incarcerations, homelessness, crack cocaine addiction.

Nevertheless, incarceration was an opportunity to screen and initiate ART, particularly for migrants and other disenfranchised populations with limited access to care. Most of the latter discover their HIV-positive status during incarceration, unlike their French-born counterpart.

As reported in the United States, routine HIV testing in correctional facility is a key intervention to diagnose HIV infections at early stages. ${ }^{37}$

Unlike in North American studies, we were not able to report race, or ethnicity, which is forbidden by French law. Nevertheless, our study highlighted that most HIV-positive inmates belonged to a minority, as this was reported in a large North American survey. ${ }^{8}$ The proportion of migrants $(69.4 \%)$ seemed higher than in the general inmate population. Surprisingly, some geographical origins were disproportionately 
Table I. Comparison of the DAI-HIV population, with the French Guiana inmate population, and with the HIV-positive population followed in Cayenne hospital.

\begin{tabular}{|c|c|c|c|c|c|c|c|}
\hline & $\begin{array}{l}\text { PLHIV inmates } \\
\text { DAI-VIH } \\
(2007-2013) \\
N=147\end{array}$ & $\begin{array}{l}\text { Inmates KAP } \\
\text { survey }(2015 \\
N=236\end{array}$ & & $\begin{array}{l}\text { Inmates } \\
\text { report } \\
N=154\end{array}$ & $\begin{array}{l}\text { UCSA } \\
(20 \mid 4)\end{array}$ & $\begin{array}{l}\text { PLHIV, hos } \\
\text { care VESPA } \\
(201 \mathrm{I}) \\
\mathrm{N}=136\end{array}$ & \\
\hline \multicolumn{8}{|l|}{ Gender (\%) } \\
\hline Male & 82.3 & 93.6 & & & & 39.6 & \\
\hline Female & 17.7 & 6.4 & $\mathrm{P}<0.0 \mathrm{I}$ & & & 60.4 & $\mathrm{P}<0.01$ \\
\hline Median age (IQR) & $\begin{array}{l}37 \\
\quad(3 \mid-44)\end{array}$ & $\begin{array}{l}29 \\
(24-39)\end{array}$ & & & & $\begin{array}{l}43 \\
\quad(35-54)\end{array}$ & \\
\hline Never attended school (\%) & 58.1 & 5.5 & $\mathrm{P}<0.0 \mathrm{I}$ & & & & \\
\hline Homeless (\%) & 31.0 & 8.5 & $\mathrm{P}<0.0 \mathrm{I}$ & & & & \\
\hline Repeat offenders (\%) & 63.9 & 46.6 & $\mathrm{p}<0.0 \mathrm{I}$ & & & & \\
\hline \multicolumn{8}{|l|}{ Country of birth (\%) } \\
\hline France & 30.6 & $4 I .1$ & $P=0.04$ & & & & \\
\hline Guyana & 39.5 & 17.0 & $\mathrm{p}<0.0 \mathrm{I}$ & & & & \\
\hline Brazil & 10.2 & 13.1 & NS & & & & \\
\hline Suriname & 14.9 & 19.9 & NS & & & & \\
\hline Haiti & 1.4 & 4.2 & NS & & & & \\
\hline Other & 3.5 & 4.7 & NS & & & & \\
\hline \multicolumn{8}{|l|}{ Addiction (\%) } \\
\hline Crack & 33.3 & 12.0 & $\mathrm{P}<0.0 \mathrm{I}$ & 9.8 & $\mathrm{P}<0.0 \mathrm{I}$ & 6.2 & $\mathrm{P}<0.01$ \\
\hline Cannabis & 44.2 & 59.4 & $\mathrm{p}<0.0 \mathrm{I}$ & 38.9 & NS & 8.3 & $\mathrm{P}<0.01$ \\
\hline \multicolumn{8}{|l|}{ Comorbidity (\%) } \\
\hline $\mathrm{HBs} \mathrm{Ag}+$ & 8.1 & & & 4.1 & $p=0.02$ & 10.1 & NS \\
\hline HTLVI & 4.7 & & & 1.0 & $\mathrm{P}<0.0 \mathrm{I}$ & & \\
\hline $\mathrm{HCV}$ & 4.1 & & & & & 2.9 & NS \\
\hline Hypertension & 10.9 & & & 4.3 & $\mathrm{P}<0.0 \mathrm{I}$ & 14.7 & NS \\
\hline Diabetes & 4.8 & & & 1.2 & $\mathrm{p}<0.0 \mathrm{I}$ & 5.3 & NS \\
\hline Asthma & 3.4 & & & 2.4 & NS & & \\
\hline Epilepsy & 2.7 & & & 0.7 & $P=0.01$ & & \\
\hline CD4 cell count $<200 / \mathrm{mm}^{3}$, all patients & $14.3^{\mathrm{a}}$ & & & & & 13.9 & NS \\
\hline On ART, all patients & $50.3^{\mathrm{a}}$ & & & & & 92.5 & $\mathrm{P}<0.01$ \\
\hline $\mathrm{VL}<50 \mathrm{cp} / \mathrm{ml}$, on ART & $83.1^{\mathrm{a}}$ & & & & & 56.6 & $\mathrm{P}<0.01$ \\
\hline $\mathrm{VL}<50 \mathrm{cp} / \mathrm{ml}$, all patients & $41.5^{\mathrm{a}}$ & & & & & 52.3 & NS \\
\hline
\end{tabular}

ART: antiretroviral therapy; DAI-HIV: $\square$; HCV: hepatitis C virus; HTLVI: $\square$; IQR: interquartile range; NS: not significant, p > 0.05; PLHIV: people living with HIV; VL: viral load. [AQ11]

${ }^{\mathrm{a}}$ Last measure before release from incarceration.

represented among HIV-positive migrant detainees, compared to the general inmate population and to the HIV-positive patients followed in the hospital. Most HIV-positive inmates were born in Guyana (formerly known as British Guiana), while this subgroup was underrepresented among the general population of inmates and among PLHIV followed in the hospital. Conversely, patients born in Haiti were a minority among the HIV-positive inmates, but were overrepresented among HIV-positive patients followed in the hospital $37.7 \%$ of cohort in the Cayenne Hospital Day Care Unit, where the majority of PLHIV is followed in French Guyana ${ }^{38}$ ).

As reported elsewhere, ${ }^{39}$ the virological outcomes of the HIV-positive inmates on ART were excellent, even surpassing those in the hospital-based population.
Nevertheless, the proportion of inmates on ART in the DAI-VIH population remains low: only $50.3 \%$ were treated versus $92.6 \%$ in the hospital cohort $(p<0.001)$. Before the release of the September 2013 French National recommendations, patients were eligible for ART if CD4 cell count was below $500 / \mathrm{mm}^{3}{ }^{28}$ Considering the CD4 cell count nadir, at least $70 \%$ of the HIV-positive inmates should have been treated, which is far below the observed proportion. Unmet needs for ART in correctional facilities have been previously reported in the U.S., despite the legal obligation to provide ART to any eligible inmates. ${ }^{40}$ The situation may be even worse in U.S. jails, where the length of stay is shorter than in prison. ${ }^{41}$ In a North American survey published in 2012, only $21 \%(12 / 58)$ of the newly diagnosed patients started ART before release, 
presumably because most of the newly diagnosed inmates were released before a pretreatment evaluation could be completed (approximately $50 \%$ of the jail detainees were released within two days). ${ }^{37}$ In our survey, HIV-positive inmates incarcerated for less than one month were excluded, therefore the above explanation does not explain low rates of treatment.

We suspect that our unmet needs may be related to the reluctance of the physician to start ART in correctional facility, assuming that the most psychosocially vulnerable patients would quickly stop the treatment after release. In addition, a significant proportion of patients refused to start ART while incarcerated: around $15 \%$ of the untreated patients in the DAIVIH population. In our experience, this was often correlated with severe psychiatric disorders or with concerns that their HIV status would be revealed. ART refusal among inmates has been already reported in an Italian survey, where it was the main explanation for the unmet need of ART. ${ }^{42}$ Nevertheless, to our knowledge, this phenomenon was not documented in other quantitative surveys and may justify further research, as this may partly explain the suboptimal prescription of ART in correctional facilities.

Our study has important limitations, and the results should be taken with caution. Comparisons with the general inmate population and with nonincarcerated HIV patients were useful to contrast the different profiles. However, these comparisons are weakened by biases: the dates of the studies, inclusion process, and data collection were different between the compared populations. Moreover, the VESPA2 population included only patients in Cayenne hospital (accounting for $60-65 \%$ of the PLHIV followed in French Guiana), which may not reflect the whole PLHIV population living in the territory. Hospital-based population was more likely to have symptomatic disease, compared to HIV-positive inmates, generally asymptomatic and diagnosed with good CD4 cell count. Due to the retrospective data collection of the DAI-VIH study, we were not able to report data such as HIV acquisition risk, health insurance coverage, marital status, income, which have been reported in other surveys. $8,18,21,23,24$

Despite these caveats, our study is original. We show the very precarious psychosocial profile of HIVinfected inmates, which is strikingly different from other comparison groups. These observations are in line with our clinical impression: hospital-based and incarcerated population of PLHIV significantly differ in psychosocial determinants and comorbidities; in addition, HIV-positive inmates seemed more vulnerable than the other inmates, which would justify special attention.
Considering these vulnerabilities, HIV-positive inmates face major challenges beyond detention: to maintain ART, avoid reincarceration, and stay alive.

Indeed, we have recently described a very high postincarceration mortality rate among males released from the French Guiana correctional facility, almost 15 times that of the general male population of the region. ${ }^{15}$

This study is an addition to the study of health problems in prison in French Guiana, ${ }^{13-15}$ a territory that has one of the highest incarceration rates in South America and a high HIV prevalence. ${ }^{26}$ It emphasizes the particularly great psychosocial vulnerability of HIV-infected persons in this context, information that may be useful for neighboring countries, and for advocating for funds to alleviate this vulnerability.

\section{Conclusion}

A significant proportion of the HIV-infected persons living in French Guiana experiences incarceration. HIV-positive inmates may share the comorbidities of the other PLHIV, with the addition of more frequent psychosocial vulnerabilities than among the general inmate population.

Despite ART availability, and excellent virological outcomes while incarcerated, unmet needs for ART were a relevant phenomenon, not completely explained by patient refusal.

Nevertheless, incarceration should be considered as an opportunity to reach minorities and high-risk population with poor access to health care.

\section{Acknowledgments}

I warmly thank Lyderic Aubert for his useful comments.

\section{Declaration of conflicting interests}

The authors declared no potential conflicts of interest with respect to the research, authorship, and/or publication of this article.

\section{Funding}

The authors received no financial support for the research, authorship, and/or publication of this article.

\section{ORCID iD}

Florence Huber (D) http://orcid.org/0000-0002-4340-0106

\section{References}

1. Combessie P. Sociologie de la prison. Paris: la Découverte, 2009.

2. Stephenson BL, Wohl DA, Golin CE, et al. Effect of release from prison and re-incarceration on the viral 
loads of HIV-infected individuals. Public Health Rep 2005; 120: 84-88.

3. Dolan K, Wirtz AL, Moazen B, et al. Global burden of HIV, viral hepatitis, and tuberculosis in prisoners and detainees. Lancet. Epub ahead of print 14 Julv 2016. DOI: 10.1016/S0140-6736(16)30466-4. [AQ4]

4. Hammett TM, Harmon MP and Rhodes W. The burden of infectious disease among inmates of and releases from US correctional facilities, 1997. Am J Public Health 2002; 92: 1789-1794.

5. Peters RH, Greenbaum PE, Edens JF, et al. Prevalence of DSM-IV substance abuse and dependence disorders among prison inmates. Am J Drug Alcohol Abuse 1998; 24: $573-587$.

6. Dolan K, Kite B, Black E, et al. Reference group on HIV/AIDS prevention and care among injecting drug users in developing and transitional countries. HIV in prison in low-income and middle-income countries. Lancet Infect Dis 2007; 7: 32-41.

7. Semaille C, Le Strat Y, Chiron E, et al. Prevalence of human immunodeficiency virus and hepatitis $\mathrm{C}$ virus among French prison inmates in 2010: a challenge for public health policy. Euro Surveill 2013; 18. [AQ5]

8. Ammon B, Iroh $\mathrm{P}$, Tiruneh $\mathrm{Y}$, et al. HIV care after jail: low rates of engagement in a vulnerable population. J Urban Health 2018; 95: 488-498.

9. Murphy M, Gaffney K, Carey O, et al. The impact of HIV disease on an Irish prison population. Int J STD AIDS 1992; 3: 426-429.

10. Kendig N, Stough T, Austin P, et al. Profile of HIV seropositive inmates diagnosed in Maryland's state correctional system. Public Health Rep 1994; 109: 756-760.

11. Ekouevi DK, D'almeida S, Salou M, et al. HIV seroprevalence among inmates in Togo. Med Mal Infect 2013; 43: 279-285.

12. About V. Rapport annuel d'activité de l'Unité de Soins et de Consultations (UCSA) de l'établissement pénitentiaire de Rémire Montjoly, 2014. [AQ6]

13. Nacher M, Ayhan G, Arnal R, et al. Hign prevalence rates for multiple psychiatric conditions among inmates at French Guiana's correctional facility: diagnostic and demographic factors associated with violent offending and previous incarceration. BMC Psychiatry. Epub ahead of print 2018. DOI: 10.1186/s12888-018-1742-7.

14. Ayhan G, Arnal R, Basurko C, et al. Suicide risk among prisoners in French Guiana: prevalence and predictive factors. BMC Psychiatry. Epub ahead of print 2017. DOI: $10.1186 / \mathrm{s} 12888-017-1320-4$.

15. Huber F, Merceron A, Madec Y, et al. High mortality among male HIV-infected patients after prison release: ART is not enough after incarceration with HIV. PLoS One 2017; 12: e0175740.

16. Merceron A. Pronostic et suivi médical des personnes infectées par le VIH, libérées du centre pénitentiaire de Remire-Montjoly entre 2007 et 2013, 2015. [AQ7]

17. Bulsara SM, Wainberg ML and Newton-John TRO. Predictors of adult retention in HIV care: a systematic review. AIDS Behav 2018; 22: 752-764.
18. Chen NE, Meyer JP, Avery AK, et al. Adherence to HIV treatment and care among previously homeless jail detainees. AIDS Behav 2013; 17: 2654-2666.

19. Springer SA, Pesanti E, Hodges J, et al. Effectiveness of antiretroviral therapy among HIV-infected prisoners: reincarceration and the lack of sustained benefit after release to the community. Clin Infect Dis 2004; 38: 1754-1760.

20. Clements-Nolle K, Marx R, Pendo M, et al. Highly active antiretroviral therapy use and HIV transmission risk behaviors among individuals who are HIV infected and were recently released from jail. Am J Public Health 2008; 98: 661-666.

21. Loeliger KB, Altice FL, Desai MM, et al. Predictors of linkage to HIV care and viral suppression after release from jails and prisons: a retrospective cohort study. Lancet HIV. Epub ahead of print 27 November 2017. DOI: 10.1016/S2352-3018(17)30209-6.

22. Baillargeon JG, Giordano TP, Harzke AJ, et al. Enrollment in outpatient care among newly released prison inmates with HIV infection. Public Health Rep 2010; 125: 64-71.

23. Felisberto M, Saretto AA, Wopereis S, et al. Prevalence of human immunodeficiency virus infection and associated risk factors among prison inmates in the city of Florianópolis. Rev Soc Bras Med Trop 2016; 49: 620-623.

24. Meyer JP, Zelenev A, Wickersham JA, et al. Gender disparities in HIV treatment outcomes following release from jail: results from a multicenter study. Am J Public Health 2014; 104: 434-441.

25. Nacher M, Adenis A, Hanf M, et al. Crack cocaine use increases the incidence of AIDS-defining events in French Guiana. AIDS 2009; 23: 2223-2226.

26. Nacher M, Vantilcke V, Parriault MC, et al. What is driving the HIV epidemic in French Guiana? Int $J$ STD AIDS 2010; 21: 359-361.

27. Parriault M-C, Van-Melle A, Basurko C, et al. Sexual risk behaviors and predictors of inconsistent condom use among crack cocaine users in the French overseas territories in the Americas. Int $J$ STD AIDS 2017; 28: 1266-1274.

28. France, Ministère des affaires sociales et de la santé (2012- ...), Morlat P. Prise en charge médicale des personnes vivant avec le VIH rapport 2013: recommandations du groupe d'experts. Paris: DILA - Direction de l'information légale et administrative: La documentation française, 2013. [AQ8]

29. Dray-Spira R, Spire B and Lui F. General method of the ANRS-VESPA2 ctudy. Bull Épidémiol Hebd 2013; 321-324. [AQ9]

30. Lert F, Aubriere C, D'Almeida Wilson K, et al. Social status and health conditions of persons living with HIV in French West Indies, French Guiana, and Reunion Island in 2011. First results of the ANRS-VESPA? survey. Bull Épidémiol Hebd 2013; 300-307. [AQ10]

31. Chaponnay A. Connaissances, attitudes et pratiques des détenus du centre pénitentiaire de RémireMontjoly (Guyane Française) vis-à-vis du VIH et des IST, 2015. 
32. Spaulding AC, Seals RM, Page MJ, et al. HIV/AIDS among inmates of and releases from US correctional facilities, 2006: declining share of epidemic but persistent public health opportunity. PLoS One 2009; 4: e7558.

33. Wacquant L. Les prisons de la misère. Paris: Raisons d'agir, 2015.

34. Allen DM, Lehman JS, Green TA, et al. HIV infection among homeless adults and runaway youth, United States, 1989-1992. Field Services Branch. AIDS 1994; 8: $1593-1598$.

35. Annequin M, Lert F, Spire B, et al. Increase in unemployment over the 2000's: comparison between people living with HIV and the French general population. PLoS One 2016; 11: e0165634.

36. Krueger LE, Wood RW, Diehr PH, et al. Poverty and HIV seropositivity: the poor are more likely to be infected. AIDS 1990; 4: 811-814.
37. de Voux A, Spaulding AC, Beckwith C, et al. Early identification of HIV: empirical support for jail-based screening. PLoS One 2012; 7: e37603.

38. Corevih G. Rapport d'Activité. Cayenne: Centre Hospitalier de Cayenne, 2015.

39. Davies N and Karstaedt A. Antiretroviral outcomes in South African prisoners: a retrospective cohort analysis. PLoS One 2012; 7: e33309.

40. Zaller N, Thurmond $\mathrm{P}$ and Rich JD. Limited spending: an analysis of correctional expenditures on antiretrovirals for HIV-infected prisoners. Public Health Rep 2007; 122: 49-54.

41. Wohl DA and Rosen DL. Inadequate HIV care after incarceration: case closed. Lancet HIV 2018; 5: e64-e65.

42. Monarca R, Madeddu G, Ranieri R, et al. HIV treatment and care among Italian inmates: a one-month point survey. BMC Infect Dis 2015; 15. 